\title{
船舶の亜鉛防食とその効果*
}

\author{
菅野 照造** 多田 義典** 三浦 達男**
}

\section{Cathodic Protection of Ship Hulls and Its Effectiveness}

\author{
Teruzo Sugano, Yoshinori Tada and Tatsuo Miura
}

The galvanic protection of ship hulls with zinc anodes has become the most popular and conventional technic to day, but its actual effectiveness had been still in veil.

The authors applied this process to the new bybuilt ships of identical type (five 10,000 DWT class diesel cargo ships) and obtained the best result when zinc plate's disposition was designed to give;

1) $0.7 \sim 0.9 \mathrm{~A} / \mathrm{m}^{2}$ as propeller side

2) $2.2 \mathrm{~mA} / \mathrm{m}^{2}$ as oil type painted hull.

\section{1. 緒言}

船舶外板没水部に亜鉛を装着して防食を行なうことは 今日すでに常識化され一般に普及されているが，その効 果打よび塗装との関連性等については試験片による報文 を数多く見受けるのみで，実船につき計測した例はごく 少ないようである。筆者らは同型の新造船，およびその 他の新造船につき，これらの計測を行なら機会を得，一 応その効果を確認することができたので, その概要を報 告し各位の御批判を仰ぐ次第である。

\section{2. 研究計画}

各船主の御好意により当社建造になる 新造船, 鉄隆 丸, 協泰丸, 三雲丸, 協明丸, 協新丸, 協瑞丸および当 社曳船松丸等を研究対象船舶として下記項目にわたって 実船計測を行なった。

（1）亜鉊板の取付個数と主として艤装中の船体電位 との関係。

(2) 航行中の船体電位の変化について。

（3）亜鉊による電気防食の効果。

研究対象船舶の主要目は第 1 表の通りである。

第1表 研究対象船舶の主要目

\begin{tabular}{|c|c|c|c|c|c|c|c|c|}
\hline 船 & & 名 & 载貨重量 & 全 長 & 巾 & 架さ & 主機械 & 最高速力 \\
\hline 協 & 泰 & 丸 & $\begin{array}{r}\text { DWT } \\
11,927\end{array}$ & $\begin{array}{c}\mathrm{m} \\
130.00^{2}\end{array}$ & 18.20 & $\stackrel{\mathrm{m}}{11.60}$ & デイゼル & $\begin{array}{c}\mathrm{kt} \\
17.3^{2}\end{array}$ \\
\hline & 雲 & 丸 & 9,155 & 117.29 & 16.80 & 10.40 & " & 15.1 \\
\hline 協 & 明 & 丸 & 11,004 & 130.00 & 18.20 & 11.60 & $" 1$ & 17.6 \\
\hline 協 & 新 & 丸 & 11,978 & 139.90 & 18. 20 & 11.60 & " & 17.2 \\
\hline 協 & 瑞 & 丸 & 11,770 & 139.90 & 18. 20 & 11.60 & " & 17.3 \\
\hline \multicolumn{3}{|c|}{ 松丸(电船) } & 64 & 21 & 5.5 & 2.7 & 蒸気機関 & 11.0 \\
\hline
\end{tabular}

* 昭和33年11月18日学振主催第 2 回防食技術研究討論会にて発表

** 石川島重工莱株式会社

\section{3. 結果および考察}

（1）垔鉿の取付個数と，主として艤装中の船体電位 との関係

従来船舶の船尾外板付近に取付ける亜鉛の個数は，た だ習慣に従って取付けていたにすぎず，取付数の決定に はなんらの根拠なしに行なわれていたが，亜欽陽極とし ての研究が盛んに行なわれ, その全貌が明らかになるに 従い亜鈶からの発生電流がかなり明確に把握できるよう になったので, 所要防食電流の決定と同時に自ずとその 取付個数が決められるようになった。

高純度亜鉊の発生電流密度は今までの実績から $0.3 〜$ $1.2 \mathrm{~m} \mathrm{~A} / \mathrm{cm}^{2}$ とされているので, これらの数值をもとに して研究対象船舶の中最子代表的な協泰丸, 協明丸, 三 雲丸の 3 船につき計測を行なった。対象船舶の洤装およ び覀鉊板の装着要領（取付けはすべて溶着方法で行なっ た）は第 2 表に示した通りである。すなわち協明丸は従 来の取付個数に従って取付けたもので，協泰丸は船底部 の完全防食を試みて従来の取付個数の約 2 倍量に相当す る亜鈶を取付けた。三雲丸は船主の御要望もあって，外 板は電動ブラッシングにて赤錆を除去した程度（くろ皮 除去までには至らない）の下地処理ののち船底塗料を塗 装したものなので, 防食塗装としては最も苛酷な条件の もとで行なわれた訳である。このようにそれぞれ異なっ た条件のもとに進水した各船舶の艤装期間中に括ける船 体電位（S C E）の状態は第 1〜3図の通りであった。

この結果から理想的な防食範囲内にあるのは第 1 図に 示した協泰丸のみで，他の船舶はいずれる防食電位すれ すれの範囲かあるいはそれより貴な電位を示しており, 船体電位は船尾から船首に向って貴となる勾配を示して いた。これは協明丸，三雲丸とも船尾に集中して亚鈶板 


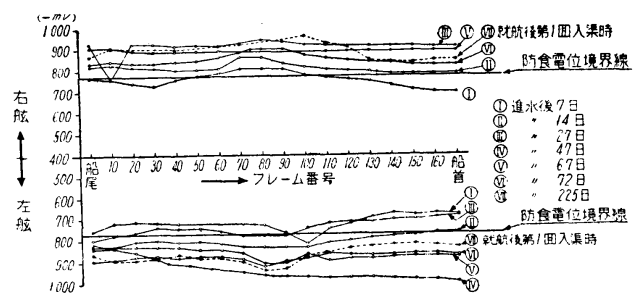

第 1 図 協泰丸觲装期間中に和ける船体電位変 化曲線 (32.3.18〜5.22)

を取付けているのに対して，協泰丸では第 2 表に示した ごとく，船体中央部のビルジキール付近に約 $3 \mathrm{~m}$ 間隔で 亜鉛板を取付けたためと孝えられる。

このよ5に亜鉊陽極の近傍は防食電流の印加により容 易に分極効果を示すが，その点から距たるに従ってこれ らの影響が小となるため電位勾配が生ずるものと考えら れる。したがって外板防食を考劣る場合最少限度の亜鉛 板取付個数で最大の効果を得ようとする場合には, 船尾 付近にプロペラを分極させるに必要な個数の他は点々と

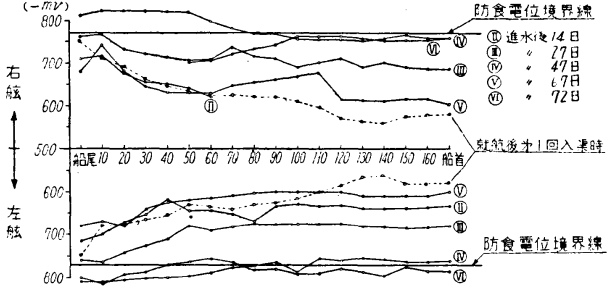

第 2 図 協明丸艤装期間中における船体電位変 化曲線 (32.5.12 9.9)

（注）右舷のフレーム10 船首までは未測定

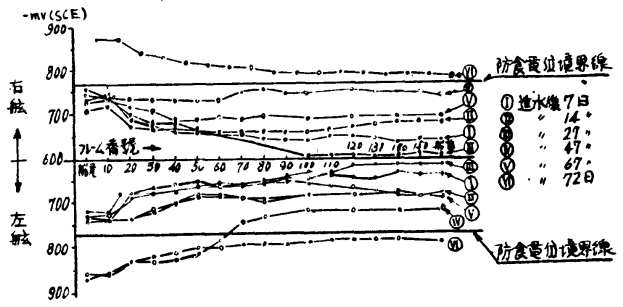

第3 図 三雲丸艤装期間中に打ける船体電位变 化曲線 (32.4.3〜 7.17)

第 2 表 研究対象船舶の塗装および覀鉛装着要領

\begin{tabular}{|c|c|c|c|c|c|c|c|c|c|c|c|c|c|c|c|}
\hline \multirow{3}{*}{ 船 } & \multirow{3}{*}{\multicolumn{2}{|c|}{ 名 }} & 塗 & 装 & 要 領 & \multirow{3}{*}{ 酧 } & 鉛 & 板 & 装 & 要 & 領 $(Z A P)$ & & 船 体 & 浸 水 面 & 皘 $\mathrm{m}^{2}$ \\
\hline & & & \multirow{2}{*}{\multicolumn{2}{|c|}{ 船 底 部 }} & \multirow{2}{*}{ 水 線 部 } & & \multicolumn{3}{|c|}{ 船 } & & 体 & \multirow{2}{*}{ 合 } & \multirow{2}{*}{ 軽荷状態 } & \multirow{2}{*}{ 灌载状態 } & \multirow{2}{*}{ プロペラ } \\
\hline & & & & & & & 船尾 & & 中 & 央 & 部 & & & & \\
\hline 協 & 泰 & 丸 & $\begin{array}{ll}\mathrm{W} / \mathrm{P} & 1 \\
\mathrm{~A} / \mathrm{C} & 3 \\
\mathrm{~A} / \mathrm{F} & 2 \\
\end{array}$ & $\begin{array}{l}1 \text { 回 } \\
3 \text { " } \\
2 \prime \prime\end{array}$ & $\begin{array}{ll}\mathrm{W} / \mathrm{P} & 1 \text { 回 } \\
\mathrm{A} / \mathrm{C} & 3 \\
\mathrm{~B} / \mathrm{T} & 2 \prime \prime\end{array}$ & 14枚 & 28枚 & & FrNo & $\begin{array}{c}\text { o } 70 \sim 100,3 n \\
48 \text { 呚 }\end{array}$ & n 間隔 & 90枚 & 2160 & 3870 & 17.8 \\
\hline 協 & 明 & 丸 & $\begin{array}{ll}\text { W/P } & 1 \\
\mathrm{~A} / \mathrm{C} & 3 \\
\mathrm{~A} / \mathrm{F} & 2 \\
\end{array}$ & $\begin{array}{l}1 \text { " } \\
3 \text { " } \\
2 \text { " }\end{array}$ & $\begin{array}{lll}\mathrm{W} / \mathrm{P} & 1 & \\
\mathrm{~A} / \mathrm{C} & 2 \prime \prime \\
\mathrm{B} / \mathrm{T} & 2 \prime \prime\end{array}$ & $14 \prime \prime$ & $28 \prime \prime$ & & & - & & $42 \prime \prime$ & 2160 & 3870 & 17.8 \\
\hline & 雲 & 丸 & $\begin{array}{ll}\mathrm{A} / \mathrm{C} & 3 \\
\mathrm{~A} / \mathrm{F} & 1\end{array}$ & $\begin{array}{l}3 \prime \prime \\
1 " \prime\end{array}$ & $\begin{array}{l}\mathrm{A} / \mathrm{C} 2 " \prime \\
\mathrm{B} / \mathrm{T} 2 "\end{array}$ & $12 \prime \prime$ & $19 \prime \prime$ & & & - & & $31 " \prime$ & 1820 & 3250 & 9.3 \\
\hline 協 & 新 & 丸 & $\begin{array}{ll}\text { W/P } & 1 \\
\mathrm{~A} / \mathrm{C} & 4 \\
\mathrm{~A} / \mathrm{F} & 1\end{array}$ & $\begin{array}{l}11 " \\
4 \prime \prime \\
1 " \prime\end{array}$ & $\begin{array}{lll}\mathrm{W} / \mathrm{P} & 1 & \prime \prime \\
\mathrm{A} / \mathrm{C} & 2 & \\
\mathrm{~B} / \mathrm{T} & 2 & \end{array}$ & $14 \prime \prime$ & $32 \prime \prime$ & & & - & & $46 " \prime$ & 2500 & 3900 & 17.8 \\
\hline & 瑞 & 丸 & $\begin{array}{ll}\text { W/P } & 1 \\
\mathrm{~A} / \mathrm{C} & 4 \\
\mathrm{~A} / \mathrm{F} & 1\end{array}$ & $\begin{array}{l}1 " \\
4 \prime \prime \\
1 \prime \prime\end{array}$ & $\begin{array}{ll}\mathrm{W} / \mathrm{P} & 1 \prime \prime \\
\mathrm{A} / \mathrm{C} & 2 \prime \prime \\
\mathrm{B} / \mathrm{T} & 2 \prime \prime\end{array}$ & $\left(\begin{array}{r}\mathrm{ZA} \mathrm{AP} \\
-\mathrm{A}\end{array}\right)$ & $\left(\begin{array}{c}28 \prime \prime \\
\text { ZAP } \\
-\mathbf{A}\end{array}\right)$ & $\begin{array}{c}\text { FrNo } \\
\prime \prime \\
\prime \prime \\
\prime \prime \\
\prime \prime\end{array}$ & $\begin{array}{l}50 \text { 付近 } \\
80 " \prime \\
80 " \\
125 \\
125\end{array}$ & 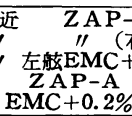 & 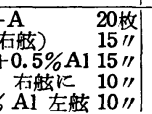 & $110 " \prime$ & 2500 & 3900 & 17.8 \\
\hline
\end{tabular}

（注）重鉐の寸法は協瑞丸を除いては $25 \times 150 \times 300 \mathrm{~mm}$ ，協瑞丸は $20 \times 100 \times 500 \mathrm{~mm}$

間隔を打いて亜鈶を装着することが理想的である。

たとえば亜鉛板 1 個の発生電流を $0.3 \mathrm{~A}$ とし，船体の 所要防食電流密度を $10 \mathrm{~m} \mathrm{~A} / \mathrm{m}^{2}$ とすると, 亜鉛板 1 個 の防食面積は $30 \mathrm{~m}^{2}$ であるから，この円の直径は約 $6 \mathrm{~m}$ となりこれが適当な取付間隔となる。

しかしこのよ 5 な取付け方法は亜鉊の断面積が大きく なるので推進抵抗に影響を及ぼし，高速船の場合には採 用し難いことが試運転の結果問題となったので，更に取 付方法を改良し第 4 図のごとく帯状に取付けることに し，協瑞丸においてこれを実施した。このときの艤装期 間中に拉ける船体電位は第 5 図のごとくで, これは第 1 図の協泰丸のよ5に電位分布は船尾から船首にかけて一 様となり理想的な状態であった。

(2) 航行中の船体電位変化

一般商船に拈いては航海中の防食を主眼に考えなけれ

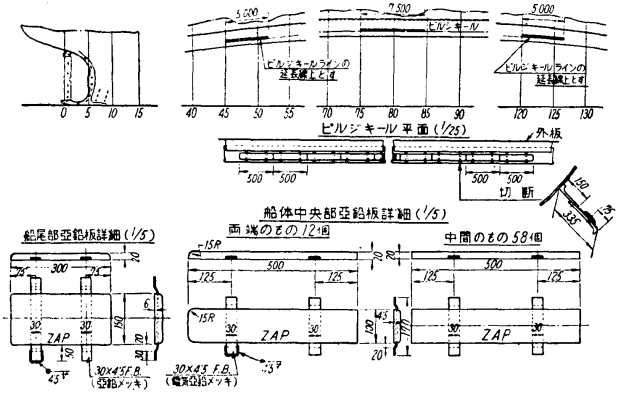

第4 図 保護亜鉛板配置（外板展開図上のもの を示す)

ばならない。それには航海中の船体電位がどのように変 化するかを知る必要がある。そこでわれわれは航行中の 船体電位の測定方法につき当社曳船松丸を用いて次の 2 項目につき実験を行なった。 


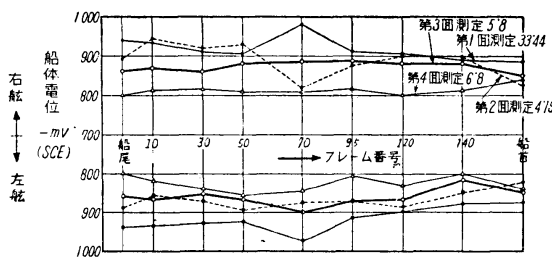

第 5 図協瑞丸艤装期間中の船体電位

（a）船体船底部にあらかじめ電極を固定して测定す る方法

（b）電極を曳行して測定する方法

使用電極はすべて海水甘承電極を用いた。固定電極は 右舷側の水線下約 $1.5 \mathrm{~m}$ 付近に溶着带により締めつけて 固定し，曳船電極は 2 分径のマニラロープで曳行して同 時に測定を行ない, 航速および曳行距離と電位变化との 関係を調査した。この結果固定電極と曳航電極との間に は測定上の許容誤差程度の差しか認められず, 約 $50 \mathrm{~m}$ の 曳航電極と固定電極との差は数 $\mathrm{m} V$ であった。また航速 と船体電位との関係は第 6 図に示したごとく，航速とと もに船体電位が高くなり貴な電位に傾くことがわかっ た。松丸の場合には $9 \mathrm{kt}$ で約 $180 \mathrm{mV}$ の電位上昇が認 められた。この現象は海水の流動による拡散層の減少に より濃度分極が減少する結果を示すものであるゆえ，大 型船舶についても小型船と同様なことが考えられる訳で める。

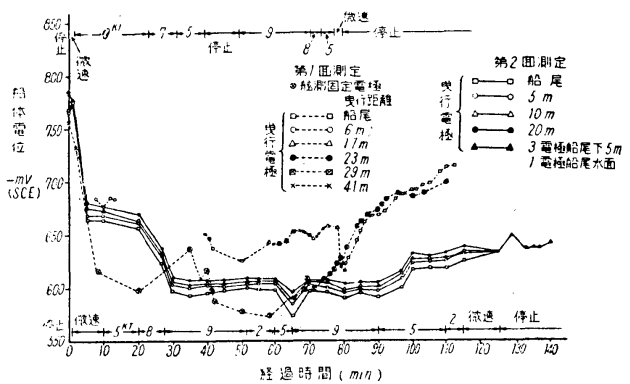

第 6 図 松丸航行中に括ける船体電位測定結果

以上のような予備試験により航行中の船体電位は曳行 電極により容易に测定できることが明らかとなったの で, 協新丸，協瑞丸の大型貨物船にこの方法を適用し実 測を試みた。計測はいずれもこれら船舶の試運転時に行 なったものでその結果は第7 図の通りである。

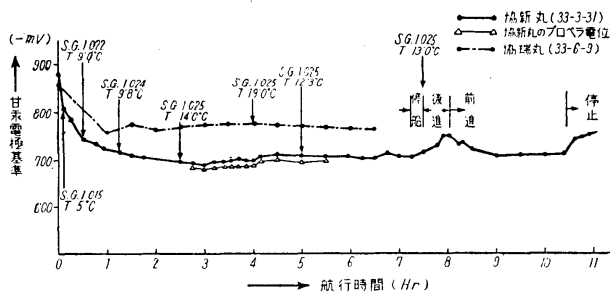

第7図大型貨物船の航行中電位变化 （S.G.は海水の比重を示す）
この結果から大型貨物船でも航行中の船体電位は停泊 時に比して 120〜 $150 \mathrm{~m} \mathrm{~V}$ の電位上昇があるものと推定 される。ゆえに船底部の完全防食を考える場合，すなわ ち航行中に $-770 \mathrm{~m} \mathrm{~V}$ 以下の電位を維持するためには艤 装中または停泊中に少なくとも $-900 \mathrm{~m} \mathrm{~V}$ 以下の電位と なっていなければならないと言えよう。このことから協 泰丸, 協瑞丸の防食状況は, 船体電位の上からはほぼ理 想的な状態であるといえる。

\section{（3）覀鉛による電気防食の効果}

研究対象船舶の5ち協泰丸が昭和32年10月22日, 協明 丸が33年 2 月 15 日，続いて 17 日に三雲丸が 入港したの で，それぞれ入渠前の船体電位を測定した。その結果は 第 8 図のごとくで，この図からも明らかなように，完全 防食を計画した協泰丸は船体電位の上からは防食範囲内 にあってきわめて満足す心゙きものであった。他の 2 船は いずれも防食電位をはるかに上回る貴な電位を示し防食 環境にあるとはいい難い状態であった。入渠時の状況は 次の通りである。

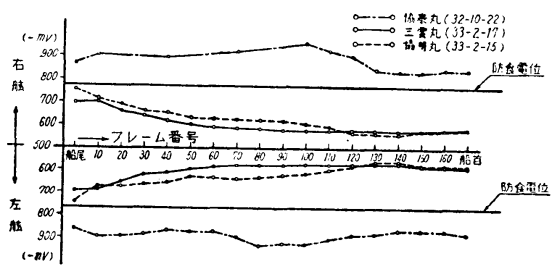

第 8 図研究対象船舶の就航後第 1 回入渠時に おける船体電位変化曲線 (S C E)

\section{（a）協 泰 丸}

本船は約 5 力月就航後入渠したもので，船体電位の状 況は前述のごとくきわめて良好な状態であった。このこ とを裏付けるがごとく，水線以下船底部全面にわたって 腐食個所を調查したが，錆および腐食が発生もしくは進 行している個所は肉眼では全然認めることができなかっ た。一般に進水時の盤木跡は塗膜が最も損稘を受け易 く,したがって腐食の被害を最もこうむり易い個所であ るが, 本船では全然そのような跡は見受けられなかっ た。その外に船底部の鋲頭は孔食を受ける代表的な個所 で，その対策には船底塗料を十分ていねいに塗るより他 に方法がなく永年苦虑してきた個所であるがこの部分も 一部塗膜が剥離しているにもかかわらず，全然発銹して おらず全く良好な状態であった。プロペラ付近の状態も なんら異状なく良好な状態であった。

\section{(b) 協 明 丸}

本船の艤装期間および入渠前の船体電位の状態は大体 三雲丸と同様で，いずれも防食電位に達せず平均約 $635 \mathrm{~m} \mathrm{~V}$ (S C E) であった。しかし三雲丸と異なる点は 塗装の前処理が完全に行なわれていた点である。したが って三雲丸ほど塗膜の劣化が目立たず比較的良好な状態 
であった。しかし発銹個所は船底部のあちこちに散在し て認められた。プロペラ付近は特に異状は認められず良 好な状態であった。

\section{(c) 三雲 丸}

本船は船底外板部の塗膜の劣化が予想以上に進行して 扣り，水線部は $\mathrm{A} / \mathrm{C}, \mathrm{B} / \mathrm{T}$ 間で約 $10 \%$ 程度が剥離し 発銹もやや全面にわたって見受けられ，特に船首付近で は著しい銹が見受けられた。船底部は発銹部分よりもし ろ海洋生物類の付着が著しくやや全面にわたってフジッ ボ，セルプラが付着していた。

本船の状態からみて船底部の防食塗装は完全デスター リング後 W/P 1 回, A/C 2 回, A/F 2 回, B/T 2 回 は最低限度の塗装として行ならべきであることが痛感さ れた。

\section{（4）対象船舶の亜鉿消耗量と所要防食電流密度}

各対象船舶の入渠時にそれぞれ装着亚鉊を取除きその 消耗量を計測した。その值から発生電流を逆算すると第 3 表のごとくになる。このうち亜鉊の自己消耗率を上部 10\%，下部 $20 \%$ としのはプロペラ付近の流体变化によ る物理的な消耗率から仮定した值である。

第3 表 研究対象船舶の取付亜鉛消耗量の比較

\begin{tabular}{|c|c|c|c|c|c|c|c|}
\hline 船名 & \multicolumn{2}{|c|}{ 取 付 位 直 } & 個数 & $\begin{array}{c}\begin{array}{c}\text { 消耗量 } \\
(\mathrm{kg})\end{array} \\
\text { (kg) }\end{array}$ & $\begin{array}{l}\text { 発生電気量 } \\
(\mathrm{A} \cdot \mathrm{hr})\end{array}$ & $\begin{array}{l}\text { 発生䨋流 } \\
\text { (A) }\end{array}$ & 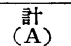 \\
\hline \multirow{3}{*}{$\begin{array}{l}\text { 協 } \\
\text { 泰 } \\
\text { 丸 }\end{array}$} & 舵 & $\begin{array}{l}\text { 上部 } \\
\text { 下部 }\end{array}$ & $\begin{array}{l}6 \\
8\end{array}$ & $\begin{array}{l}15.6 \\
25.6\end{array}$ & 28298.20 & 5.77 & \multirow{3}{*}{22.30} \\
\hline & 船 尾 & 上" & $\begin{array}{l}10 \\
18\end{array}$ & $\begin{array}{l}26.0 \\
57.5\end{array}$ & 56908.0 & 10.60 & \\
\hline & $\begin{array}{ll}\text { 船 } & \text { 体 } \\
\text { 中 } & \text { 央 }\end{array}$ & 上" & $\begin{array}{l}22 \\
26\end{array}$ & $\begin{array}{l}19.8 \\
23.4\end{array}$ & 31881.6 & 5.93 & \\
\hline \multirow{2}{*}{$\begin{array}{l}\text { 協 } \\
\text { 势 }\end{array}$} & 施 & 卡” & $\begin{array}{l}8 \\
8\end{array}$ & $\begin{array}{l}20.8 \\
27.8 \\
\end{array}$ & 33587.2 & 6.32 & \multirow[b]{2}{*}{16.31} \\
\hline & 船 尾 & 上” & $\begin{array}{r}8 \\
18\end{array}$ & $\begin{array}{l}21.3 \\
56.8\end{array}$ & 52980.2 & 9.99 & \\
\hline \multirow{2}{*}{$\begin{array}{l}\text { 垩 } \\
\text { 丸 }\end{array}$} & 舵 & $\begin{array}{l}\text { 上" } \\
\text { 点” }\end{array}$ & $\begin{array}{l}6 \\
6\end{array}$ & $\begin{array}{l}18.8 \\
20.7\end{array}$ & 27437.2 & 5.17 & \multirow{2}{*}{13.57} \\
\hline & 船 尾 & $\frac{\text { 卡” }}{\text { 下" }}$ & $\begin{array}{r}6 \\
13\end{array}$ & $\begin{array}{l}19.8 \\
45.7\end{array}$ & 44575.2 & 8.40 & \\
\hline
\end{tabular}

（注）（1）取付位置の上部, 下部とはプロペラ軸より上を上部とし 下を下部とした。船体中央部の上部，下部はごルジキールを 境とした。

（2）覀鉿の自己公食率は上部を $10 \%$ とし，下部を $20 \%$ として 計算した。

（3）垔鉙の発生電気量は $820 \mathrm{~A} \cdot \mathrm{hr} / \mathrm{kg}$ として計算した。

（4）覀鉿の浸水日数は協泰丸 223日，協明丸 221日，三零丸 221日として算出した。

これらの值と入渠時における船体の防食状況等を総合 的にみて，プロペラ付近および船体を防食するに必要な 防食電流について次のように考えた。

すなわち協明丸，三雲丸は亜鈶の取付けてある船尾プ ロペラ付近のみが $-700 \mathrm{mV}$ 前後で他の部分は一様に一 $600 \mathrm{mV}$ 前後であることは, 船尾に取付けた亜鉛からの 発生電流の大部分がプロペラに吸収されごくわずかの電
流がその近傍に印加されていると考えられる。ゆえに協 明丸，三雲丸に取付けた亜鉊の平均発生電流 $16.3 \mathrm{~A}$, 13.6Aは全部プロペラに吸収されたと仮定すると，プロ ペラに印加される電流は $0.9 \mathrm{~A} / \mathrm{m}^{2}, 1.5 \mathrm{~A} / \mathrm{m}^{2}$ となる。 しかしいずれの場合もフレーム 20 付近まではー $700 \mathrm{~m} \mathrm{~V}$ 前後になっていることから, 発生電流の全部がプロペラ に印加されたと考えるよりはそのうちの約 80〜90\% が プロペラに，20〜10\% が船尾付近の 船体に 印加された と考えるのが妥当であろ5。

この考方方やや標準塗装を行なっている協明丸につ いていえば発生電流 16.3A のうち約 13〜15A がプロ ペラに印加されたことになる。すなわちプロペラの所要 電流密度は $0.7 \sim 0.9 \mathrm{~A} / \mathrm{m}^{2}$ であるといえよ5。これを更 に協泰丸にあてはめてみると，22.3-14=8.3A がプロ ペラ以外の船体に印加されたことになり，この電流密度 は約 $2.2 \mathrm{~mA} / \mathrm{m}^{2}$ (满載時) となる。

以上装着覀鉊の消耗量から就航時における所要防食電 流を入渠前後の船体電位および防食状況から考えてみた が, 新造船の処女航海から $1 \sim 2$ 年間の船体防食に当っ ては十分ていねいな防食塗装を施した船船における亜鉛 を用いた電気防食に括いては，船底付近と船体とを分け て次のごとくいうことができるであろう。

(a) 船尾プロペラ付近の亜鉛装着要領は, プロペラ に $0.7 \sim 0.9 \mathrm{~A} / \mathrm{m}^{2}$ の電流が印加されるよ5取付けるべ きである。

（b）船尾以外の船底部の防食にあたっては $2.2 \mathrm{~mA} /$ $\mathrm{m}^{2}$ の防食電流が印加されるよう亜鈶を取付ける。 $25 \times$ $150 \times 300 \mathrm{~mm}$ の亜鈶 1 個の発生電流を $0.3 \mathrm{~A}$ とし, 船体 の所要防食電流密度を $2.2 \mathrm{~m} \mathrm{~A} / \mathrm{m}^{2}$ とすれば取付間隔は 約 $13 \mathrm{~m}$ となる。

この電流密度はいずれも一般にいわれている数値より もはるかに小さい数值であるが, 新造船船においてはこ の程度の防食電流で十分である。しかし船底塗膜の健全 度いかんによって電流密度を考え补ばならないので, 船 歷を経た船舶，または船底塗膜の poor な船舶に扎いて は前記以上の電流密度を必要とすることはもちろんのこ とである。

\section{4.あとがき}

本研究に当り, 各船主殿の御好意と, 電位計測に関し 御指導を賜わった東京工業試験所第 6 部重野隼太氏なら びに経済的御協力を戴いた三井金属鉣業(株)に厚く感謝 申し上げる。

（昭和 34 年 3 月 4 日受理） 